\title{
Rancang Bangun Boost Converter Untuk Charging Baterai Unmanned Aerial Vehicle (UAV) Bertenaga Surya
}

\author{
Noer Soedjarwanto ${ }^{1}$, Mona Arif Muda ${ }^{2}$, Endah Komalasari ${ }^{3}$, Valentin Jauhari ${ }^{4}$ \\ Jurusan Teknik Elektro, Fakultas Teknik,Universitas Lampung \\ Jl. Prof. Sumantri Brojonegoro No.1 Bandar Lampung 35145 \\ ${ }^{1}$ noersoedjarwanto@gmail. com
}

\begin{abstract}
Abstrak - Saat UAV melakukan suatu misi, UAV dituntut untuk memiliki durasi terbang yang lama sehingga misi yang dikerjakan akan bisa selesai. Durasi terbang yang pendek akan menyebabkan pekerjaan menjadi lebih lama selesainya. Konsumsi daya yang tinggi dibandingkan dengan kemampuan penyimpanan energinya yang terbatas, akan menyebabkan durasi terbang menjadi pendek. Salah satu alternatif untuk meningkatkan durasi penerbangan yaitu dengan menambahkan panel surya sebagai sumber energi tambahan. Dengan Adanya sumber energi lain yaitu menggunakan panel surya pada sistem charging baterai untuk menyuplai energi pada sistem daya di UAV, maka UAV dapat digunakan ke beban dan sekaligus dapat melakukan charging baterai. Sehingga durasi terbang dari UAV bertambah lebih lama dan memudahkan para pilot UAV atau pengguna UAV dalam melakukan charging baterai. Sistem charging baterai pada UAV bertenaga surya menggunakan DC-DC konverter yaitu boost converter. Boost converter dipilih karena dapat menghasilkan tegangan keluaran yang lebih besar dari tegangan sumber, dengan cara mengendalikan sinyal PWM (Pulse Widht Modulation). UAV tanpa panel surya hanya memiliki estimasi durasi terbang hanya 1 jam. Dengan menambah sistem charging baterai baterai pada UAV bertenaga surya estimasi durasi terbang menjadi 90 menit.
\end{abstract}

Kata kunci - UAV, DC-DC Konverter, Boost Converter, Panel Surya.

\section{PENDAHULUAN}

Perkembangan teknologi pesawat udara tanpa awak atau UAV (unmanned aerial vehicle) di dunia saat ini mulai berkembang dengan pesat dan penggunaan UAV diberbagai bidang sangatlah besar, baik dibidang militer maupun sipil. Penggunaan UAV banyak digunakan untuk pemetaan wilayah, survei daerah, foto udara dan untuk pengintaian musuh. Dalam beberapa tahun terakhir ini, tingkat kepentingan dalam pengembangan UAV untuk berbagai misi telah meningkat secara signifikan. Saat UAV melakukan suatu misi, UAV dituntut untuk memiliki durasi terbang yang lama sehingga misi yang dikerjakan akan cepat selesai. Durasi terbang yang pendek dari UAV akan menyebabkan pekerjaan menjadi lebih lama, misalnya pada kasus ketika melakukan pemetaan dan survei daerah, pilot UAV atau pengguna UAV sering dihadapkan dengan pemakaian baterai yang terlalu singkat, hal ini menyebabkan pengerjaan pemetaan maupun survei daerah menjadi lebih lama. Saat UAV beroperasi atau diterbangkan kendala yang utama yaitu konsumsi daya yang tinggi dibandingkan dengan kemampuan penyimpanan energinya yang terbatas, akan menyebabkan durasi terbang menjadi pendek. Masalah ini sudah menjadi umum bagi pilot UAV atau pengguna UAV mengenai sumber energi yang terbatas dan durasi penerbangannya yang pendek. Salah satu alternatif untuk meningkatkan durasi penerbangan atau waktu tempuh yaitu dengan menambahkan panel surya sebagai sumber energi tambahan. Dengan Adanya sumber energi lain yaitu menggunakan panel surya pada sistem charging baterai untuk menyuplai energi pada sistem daya di UAV, maka UAV dapat digunakan ke beban dan sekaligus dapat melakukan charging baterai. Sehingga durasi terbang dari UAV bertambah lebih lama dan memudahkan para pilot UAV atau pengguna UAV dalam melakukan charging baterai. Sistem charging baterai pada UAV bertenaga surya menggunakan DC-DC konverter yaitu boost converter. Boost converter dipilih karena dapat menghasilkan tegangan keluaran yang lebih besar dari tegangan sumber, dengan cara mengendailkan sinyal PWM (Pulse Widht Modulation). 


\section{STUDI PUSTAKA}

Unmanned Aerial Vehicle (UAV) merupakan wahana udara yang tidak mempunyai awak yang berada didalam pesawat. UAV dikendalikan dari jarak jauh dengan menggunakan remote control dari luar kendaraan pada jarak dan tempat tertentu. Dengan adanya UAV ini data yang diperoleh biayanya murah, aman pada kondisi cuaca kemudian lebih cepat.

Sel surya merupakan sebuah perangkat semikonduktor yang dapat mengubah energi dari matahari menjadi energi listrik DC (arus searah). Sel surya yang disusun seri atau paralel dapat menghasilkan keluaran daya sesuai yang diinginkan. Kumpulan dari sel surya ini apabila terkena paparan sinar matahari akan menghasilkan energi listrik. Energi listrik dari sel surya ini dapat disimpan didalam baterai sebagai cadangan energi listrik. Sebuah sel surya secara sederhana terdiri dari dua sambungan semikonduktor yaitu bertipe $\mathrm{P}$ dan $\mathrm{N}$, apabila sambungan tersebut terkena sinar matahari maka akan terjadi aliran elektron, dari aliran elektron ini akan menghasilkan arus listrik.

Boost Converter merupakan DC-DC konverter yang menghasilkan tegangan keluaran lebih besar dari tegangan masukannya. Boost converter secara umumnya disebut sebagai step-up converter. Konverter jenis ini bekerja secara periodik ketika saklar terbuka maupun tertutup. Rangkaian boost converter ini membutuhkan beberapa komponen yaitu saklar daya, dioda dengan frekuensi tinggi, kapasitor, induktor dan resistor. Saklar yang digunakan harus memiliki respon yang cepat saat keadaan hidup dan mati. Saklar yang digunakan adalah saklar semikonduktor yaitu mosfet.

Arduino Uno merupakan sebuah papan kontroler yang bersifat sumber terbuka (open source) dan di dilamnya terdapat mikrokontroler ATMega 328P. Jumlah pin digital dan analog dari Arduino ini yaitu berjumlah 20 pin, terdari dari 14 pin digital dan 6 pin analog. Arduino ini memiliki mempunyai osilator kristal $16 \mathrm{MHz}$ serta power jack sebagai sumber catu daya dan kabel USB digunakan untuk penghubung untuk menanamkan program pada board Arduino Uno.

Rangkaian boost converter menggunakan mosfet yang dapat difungsikan sebagai saklar, jika mosfet tersebut bekerja pada kondisi saturasi. Kondisi saturasi mosfet dapat dibentuk dengan memberikan tegangan pada kaki gatesource berkisar antara 12 - 15 volt. Karena sinyal PWM yang dihasilkan oleh Arduino Uno hanya memiliki tegangan sebesar 5 volt, maka diperlukan rangkaian penguat pada mosfet yang disebut sebagai rangkaian gate driver.

Baterai dapat dikatakan elemen sekunder yang merupakan sumber arus listrik searah (DC) yang dapat berfungsi mengubah energi kimia menjadi energi listrik. Dewasa ini baterai sering digunakan pada kendaraan listrik misalnya sepeda listrik dan mobil listrik. Tidak hanya itu baterai juga digunakan untuk menyuplai energi pada UAV atau pesawat udara tanpa awak. Baterai merupakan elemen sangat penting untuk memasok energi ke komponen kelistrikan yang ada pada kendaraan listrik.

\section{METODE}

\section{A. Studi Literatur}

Sebelum menuju pada tahap realisasi perangkat keras, terlebih dahulu dilakukan pemodelan atau simulasi. Simulasi alat ini dilakukan dengan tujuan untuk memperkuat hipotesis dari penelitian ini dan memastikan bahwa metode yang dilakukan dapat direalisasikan. Softwere yang digunakan untuk simulasi alat yaitu dengan menggunakan software MATLAB. Tahap ini juga bertujuan untuk mendapatkan hasil yang sesuai dengan karakteristik dan prinsip kerja dari komponen komponen maupun program yang akan digunakan dalam merancang alat. Beberapa referensi yang dikumpulkan antara lain: pesawat udara tanpa awak atau UAV, karakteristik dari panel surya. rangkain boost converter dan Mikrokontroler Arduino.

\section{B. Perancangan dan Pembuatan Alat}

Pada perancangan perangkat keras ini digunakan untuk menentukan komponen apa saja yang digunakan. Bagian-bagian dari yang dirancang terdiri dari rangkaian boost converter, power supplay, gate driver, sensor arus, sensor tegangan dan UAV.Perancangan perangkat keras ini delengkapi dengan sensor arus dan sensor tegangan yang diberguna untuk mengetahui nilai dari tegangan masukan dan 
tegangan keluaran pada boost converter, selanjutnya akan disimpan ke dalam memori card dengan menggunakan data logger. Dari hasil perancangan ini didapatkan schematic alat yang nantinya dapat dijadikan acuan untuk pembuatan alat.

Sebelum membuat alat, terlebih dahulu membuat schematic rangkaian. schematic yang dijadikan acuan untuk pembuatan $P C B$ Layout rangkaian serta untuk menentukan komponen yang akan digunakan.

Pembuatan program untuk Arduino Uno menggunakan software Arduino Integrated Development Environment (IDE) Selanjutnya keluaran pada Arduino berupa gelombang PWM yang digunakan untuk mengontrol rangkaian boost converter.

\section{Pengujian}

Dalam tahap pengujian ini akan dilakukan untuk melihat keberhasilan alat sesuai dengan prinsip kerjanya dan referensi yang digunakan. Selain itu, saat pengujian berlangsung akan dilakukan pengambilan data data yang akan digunakan sebagai acuan untuk menganalisa hasil pengujian. Pengujian ini dilakukan di laboratorium teknik elektro. Dengan menggunakan sumber tegangan 150 volt DC untuk sumber tegangan motor induksinya.

\section{HASIL DAN PEMBAHASAN}

\section{A. Hasil Perancangan dan Realisasi Alat}

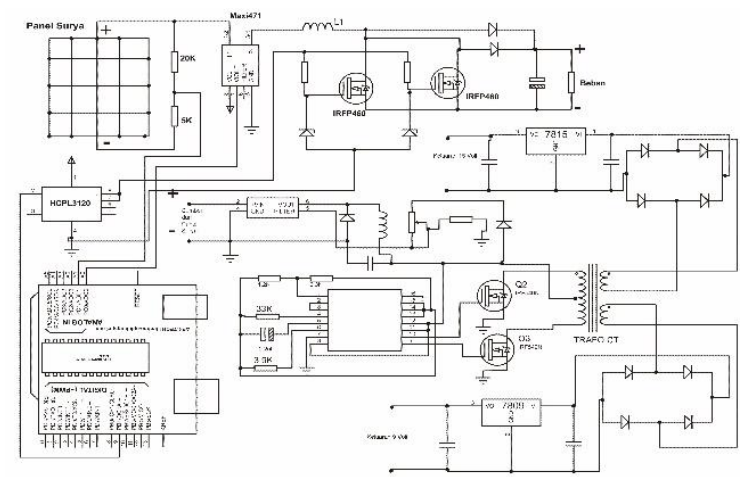

Gbr.1 Perancangan sistem charging baterai UAV bertenaga surya

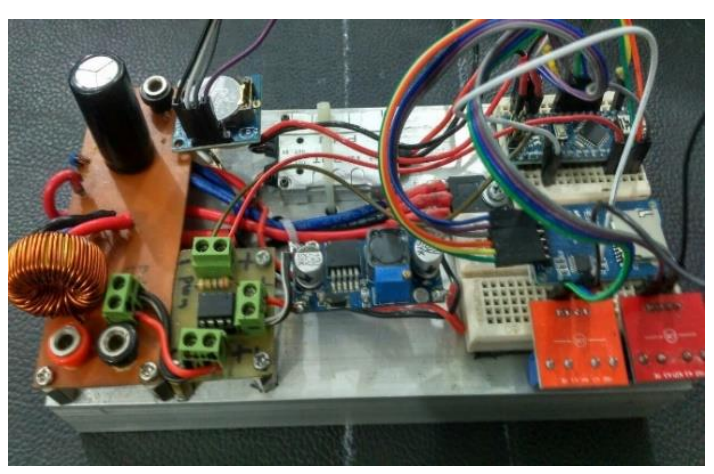

Gbr.2 Realisasi sistem charging baterai UAV bertenaga surya

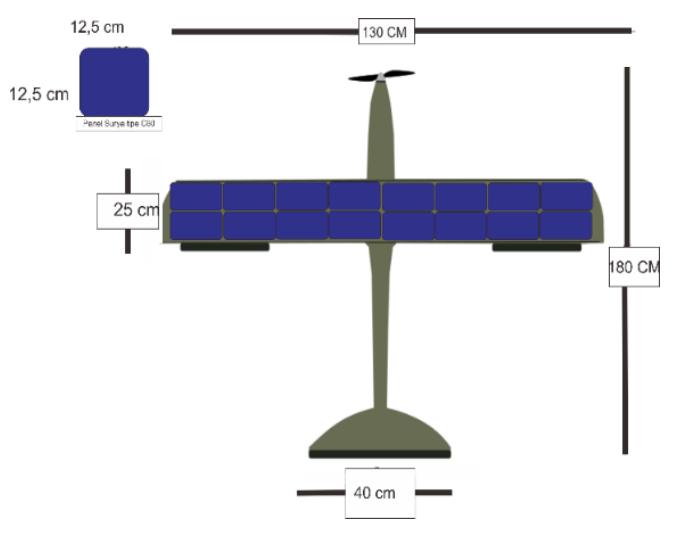

Gbr. 3 Rancangan UAV bertenaga surya

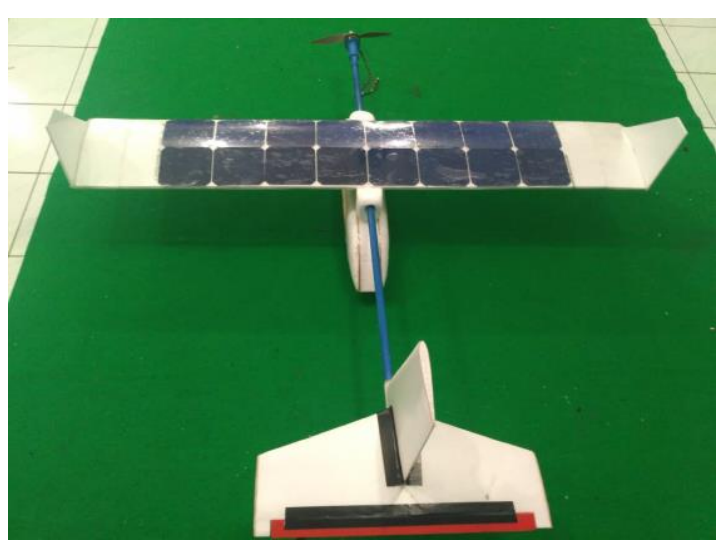

Gbr.4 Realisasi UAV bertenaga surya

Gambar 1 merupakan gambar perancangan sistem charging baterai UAV bertenaga surya. Gambar 2 merupakan gambar realisasi alat setelah melalui proses perancangan dan pembuatan skematik rangkain. Gambar 3 merupakan desain rancangan UAV. Sebelum dilakukan pembuatan UAV, terlebih dahulu dilakukan pendesainan. 
Gambar 4 merupakan realisasi UAV yang telah dirancang, yang terdapat panel surya yang berada diatas sayap UAV.

- Estimasi durasi terbang UAV tanpa penel surya.

$$
\begin{gathered}
t=\frac{\text { Daya pada baterai }}{\text { total keseluruhan kebutuhan daya elektrik }} \\
t=\frac{177,6}{177,2} \\
\mathrm{t}=1 \mathrm{jam}
\end{gathered}
$$

Maka perhitungan estimasi durasi terbang pada UAV tanpa panel surya yaitu 1 jam.

- Estimasi durasi terbang UAV bertenaga surya

$$
t=\frac{\text { Total keseluruhan sumber daya energi elektrik }}{\text { total keseluruhan kebutuhan daya elektrik }}
$$

$$
\begin{gathered}
t=\frac{228,85}{177,2} \\
\mathrm{t}=1 \text { jam } 29 \text { menit }
\end{gathered}
$$

Maka berdasarkan perhitungan estimasi durasi terbang UAV bertenaga surya yaitu 1 jam 29 menit.

\section{B. Hasil Pengujian}

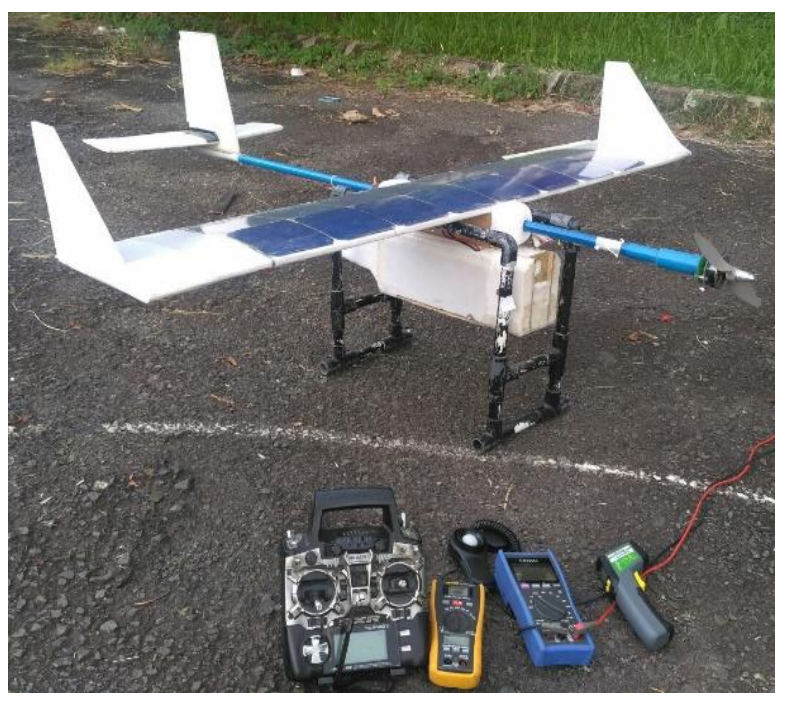

Gbr.5 Pengujian di belakang Laboratorium Terpadu Teknik Elektro

\begin{tabular}{|c|c|c|c|c|c|c|c|}
\hline Waktu & Vpv & Ipv & VBat & IBat & $\mathrm{Ppv}$ & Irr & $\mathrm{T}$ \\
\hline 09.00 & 8,8 & 0,80 & 16,4 & 6 & 7,0 & 675 & 33 \\
\hline 09.05 & 8,8 & 0,78 & 16,3 & 5,9 & 6,9 & 690 & 35 \\
\hline 09.10 & 8,7 & 0,77 & 16,3 & 5,79 & 6,7 & 763 & 36 \\
\hline 09.15 & 8,7 & 0,85 & 16,2 & 5,7 & 7,4 & 890 & 37 \\
\hline 09.20 & 8,8 & 0,88 & 15,9 & 5,6 & 7,7 & 910 & 40 \\
\hline 09.25 & 8,7 & 0,82 & 15,8 & 5,4 & 7,1 & 915 & 40 \\
\hline 09.30 & 8,5 & 0,83 & 15,7 & 5,3 & 7,1 & 918 & 41 \\
\hline 09.35 & 8,6 & 0,82 & 15,7 & 5,25 & 7,0 & 870 & 40 \\
\hline 09.40 & 8,5 & 0,93 & 15,5 & 5,2 & 7,9 & 938 & 40 \\
\hline 09.45 & 8,5 & 1,13 & 15,4 & 5,15 & 9,6 & 921 & 39 \\
\hline 09.50 & 8,4 & 0,92 & 15,3 & 5,1 & 7,8 & 885 & 38 \\
\hline 09.55 & 8,4 & 0,95 & 15,2 & 5 & 8,0 & 913 & 38 \\
\hline 10.00 & 8,4 & 0,95 & 14,9 & 4,9 & 8,0 & 912 & 40 \\
\hline 10.05 & 8,4 & 1,13 & 14,9 & 4,8 & 9,5 & 913 & 40 \\
\hline 10.10 & 8,4 & 1,16 & 14,8 & 4,8 & 9,7 & 912 & 39 \\
\hline 10.15 & 8,4 & 1,14 & 14,7 & 4,7 & 9,5 & 914 & 38 \\
\hline
\end{tabular}

Tabel 1 Pengujian durasi motor brushless pada UAV tanpa panel surya

\begin{tabular}{|c|c|c|}
\hline Waktu & $\begin{array}{c}\text { Vbaterai } \\
\text { (Volt) }\end{array}$ & $\begin{array}{c}\text { Ibaterai } \\
\text { (Ampere) }\end{array}$ \\
\hline 09:00:00 & 16,3 & 6,02 \\
\hline 09:05:00 & 15,92 & 5,7 \\
\hline $09: 10: 00$ & 15,72 & 5,6 \\
\hline $09: 15: 00$ & 15,57 & 5,4 \\
\hline $09: 20: 00$ & 15,4 & 5,3 \\
\hline $09: 25: 00$ & 15,3 & 5,2 \\
\hline $09: 30: 00$ & 15,15 & 5,1 \\
\hline $09: 35: 00$ & 14,99 & 5 \\
\hline $09: 40: 00$ & 14,86 & 4,97 \\
\hline $09: 45: 00$ & 14,76 & 4,84 \\
\hline $09: 50: 00$ & 14,6 & 4,8 \\
\hline $09: 55: 00$ & 14,45 & 4,8 \\
\hline $10: 00: 00$ & 14,34 & 4,8 \\
\hline
\end{tabular}

Tabel 2. Pengujian durasi motor brushless pada UAV bertenaga surya

Tabel 1. Pengujian durasi motor brushless pada UAV tanpa panel surya dilakukan pengambilan data setiap 5 menit sekali. Pengujian dilakukan dengan baterai Li-ion full charging yaitu 16,6 Volt sampe low baterai yaitu 14,4 Volt. Pada pengujian ini durasi motor hanya bertahan 1 jam yang artinya sama dengan hasil perhitungan. 
Tabel 2. Pengujian durasi motor brushless pada UAV bertenaga surya dilakukan pengambilan data setiap 5 menit sekali. Pengujian dilakukan dengan baterai $\mathrm{Li}$-ion full charging yaitu 16,6 Volt sampai low baterai yaitu 14,4 Volt. Pada pengujian ini durasi motor yaitu 1 jam 30 menit. Pengujian pertama dan kedua dilakukan dengan throtlte remote control sebesar $100 \%$..

\section{KESIMPULAN}

Tegangan keluaran boost converter sangat dipengaruhi oleh besarnya nilai duty cycle yang diberikan. Penggunaan sistem charging baterai dengan boost converter dapat menaikan tegangan dari 8,9 Volt menjadi 16 Volt yang artinya tegangan keluaran dari panel surya dapat digunakan untuk men-charging baterai pada UAV. Dengan adanya sistem charging baterai dan penambahan panel surya pada UAV maka durasi motor brushless yang mulanya hanya 60 menit dapat menjadi 90, sehingga penambahan durasi motor brushless pada UAV bertambah sebesar 30 menit. UAV mampu men-charging baterai dan sekaligus digunakan untuk mencatu daya pada motor brushless. Sistem ini tidak dimiliki oleh UAV-UAV pada umumnya.

\section{REFERENSI}

[1] H Rahmad, M Ronny.2016.

Pengembangan Sistem Navigasi Otomatis Pada UAV (UnmanneAerial Vehicle) dengan GPS (Global Positioning System) Waypoint. Jurusan Teknik Elektro, Fakultas Teknologi Industri, Institut Teknologi Sepuluh Nopember (ITS). Surabaya.

[2] Shofiyanti, Rizatus. 2011. Teknologi Pesawat Tanpa Awak Untuk Pemetaan dan Pemantauan tanaman dan Lahan Pertanian. Bogor: Jurnal Informatika Pertanian. Vol. 20 No.2: $58-64$.

[3] K. Eun-Mi, Y. Kee-Ho, Y. Myoung-Jong, and J. GuYoung.2011. Design considerations and modeling of asmall and low altitude solar powered UAV, International Conference on Control, Automation and Systems (ICCAS), pp. 1085- 1088.

[4] D.Y. Arfita, antonov. 2013.Pemanfaatan energi surya sebagai suplai cadangan pada laboratorium elektro dasar di institut teknologi padang. Jurnal Teknik Elektro Institut Teknologi Padang.

[5] Narkhede, Sushen, and Rajpritam. 2010. Mo deling of Photovoltaic Array (A P oject Sub mitted in Partial Fulfillment of the Requi rement for the Degree of).Departemen of El ectrical Engineering. National Institute of T echnology R ourkela-769008, Orissa.

[6] De Soto, W, S.A Klein, and W.A. Beckman. 2006. Improvement and Validati on of a Model for Photovoltaic Array Performanc e. Solar Energy 80. Hala man 78-88.

[7] M. Abdul Rahim B, M. Mordin. 2013. Interleaved DC-DC Boost Converter With Small Input Voltage. Declaration of Thesis / Undergraduate Project Paper and Copyright. Malaysia.

[8] Hart.D.W. 2011. Power Electronics International Edition. Singapura. Mc Graw Hill

[9] M.T.Afif, A. P. Pratiwi. 2015. Analisis Perbandingan Baterai Lithium-Ion,LithiumPolymer, Lead Acid Dan Nickel-Metal Hydride Pada Penggunaan Mobil Listrik.Jurnal Teknik Mesin. Pp95-99

[10] User Manual DataSheet. 2012. Arduino Comparison Guide. Colorado. SparkFun Electronics.

[11] Chamma, Bukry, 2015, Perancangan Alat Pengisi Baterai Lead Acid Berbasis Mikrokontroler ATMEGA 8535, Medan:Universitas Sumatera Utara. 